\title{
Covalently linked bisporphyrins bearing tetraphenylporphyrin and perbromoporphyrin units: Synthesis and their properties
}

\author{
PUTTAIAH BHYRAPPA ${ }^{1} *$ and V KRISHNAN ${ }^{2}$ \\ ${ }^{1}$ Department of Chemistry, Indian Institute of Technology - Madras, Chennai 600 036, India \\ ${ }^{2}$ Inorganic and Physical Chemistry, Indian Institute of Science, Bangalore 560 012, India \\ e-mail: bhyrappa@iitm.ac.in
}

MS received 20 October 2003; revised 1 March 2004

\begin{abstract}
A series of covalently linked bisporphyrins bearing meso-tetraphenylporphyrin (TPP) and octabromotetraphenylporphyrin (OBTPP) units have been synthesised and characterised. Electrochemical studies on these bisporphyrins showed an anodic shift $(\sim 30-60 \mathrm{mV})$ of the TPP unit and a cathodic shift $(\sim 40-80 \mathrm{mV})$ of OBTPP in redox potentials. Further, steady-state fluorescence studies on bisporphyrins indicated dramatic decrease in fluorescence quantum yields of the TPP moiety. Electrochemical redox and fluorescence data seem to suggest the possible existence of intramolecular interactions in these bisporphyrins.
\end{abstract}

Keywords. Bisporphyrins; brominated porphyrins; electrochemical redox; fluorescence studies.

\section{Introduction}

Bisporphyrins are of continued interest owing to their use as model compounds for energy and electron-transfer processes. ${ }^{1-7}$ Notably, these have been employed as catalysts ${ }^{8}$ and molecular hosts ${ }^{9-11}$ for the selective encapsulation of guest molecules. Various groups have reported a wide variety of bisporphyrins with varying degree of fluxionality between the porphyrin units. ${ }^{12-14}$ Direct conjugation between the porphyrin units in these systems showed interesting physico-chemical properties. ${ }^{15}$ The majority of the bisporphyrins employed thus far bear similar porphyrin units. Syntheses of bisporphyrin with dissimilar units have been reported with interesting properties. ${ }^{16-19}$

Many perhaloporphyrins have been reported in the literature with unusual physico-chemical properties. ${ }^{20}$ Furthermore, the high-valent metal complexes of perhaloporphyrins serve as robust catalysts for the oxidation of alkenes or alkanes in presence of oxygen donors. ${ }^{21}$ The higher stability of metalloperhaloporphyrin catalysts is attributed to the stabilisation of the highest occupied molecular orbitals influenced by the inductive effect of the halogen substituents. Introduction of halogens at the meso-

\footnotetext{
*For correspondence
}

phenyl groups in one of the porphyrin entities of the bisporphyrins shows interesting physico-chemical properties. ${ }^{17,18}$ Bisporphyrins with perfluoroporphyrin and tetraphenylporphyrin shows electron transfer reactions. ${ }^{19}$ Bisporphyrins with porphyrin and unbrominated porphyrin have been largely unexamined. The anodic shift of the reduction potentials and the large red-shifted absorption spectral features of perbrominated porphyrins could serve as acceptors for electron and energy transfer reactions.

In this article, we present the synthesis of bisporphyrins with meso-tetraphenylporphyrin (TPP) and octabromotetraphenylporphyrin (OBTPP), covalently linked through one of the meta or para-phenyl positions. The lengths and positions of the linkages $(m$ or $p$ ) have been varied to probe the extent of interaction in these bisporphyrins. These compounds also display interesting physico-chemical properties.

\section{Experimental section}

\subsection{Materials}

The free base porphyrins, $\mathrm{H}_{2} \mathrm{TPP}^{22}$ and $\mathrm{H}_{2} \mathrm{OBTPP}^{23}$ were synthesized using the literature methods. Metal acetates, zinc (II) acetate dihydrate and copper (II) acetate monohydrate were procured from $\mathrm{CDH}$, India and used as received. Aluminium oxide (neu- 
tral and basic) procured from Acmes (India) was used as received. 2,2-dibromodiethyl ether was prepared using the reported procedure. ${ }^{24}$ All the solvents employed were purified prior to use by standard procedures. ${ }^{25}$

\subsection{Instrumentation}

Electronic absorption spectra were recorded on a Hitachi model U-3400 and Jasco V-530 UV-Visible absorption spectrophotometers using matched quartz cells of $1 \mathrm{~cm}$ path length at ambient temperature. The ${ }^{1} \mathrm{H}$ NMR spectra of samples were performed on a Bruker WH-270 MHz FT-NMR spectrometer in $\mathrm{CDCl}_{3}$ using tetramethylsilane as the internal standard at $298 \mathrm{~K}$. Steady-state fluorescence measurements were carried out on a model MPF 44A, 65060 fluorescence spectrophotometer in quartz cells of $10 \mathrm{~mm}$ path length at ambient temperature. Cyclic voltammetric measurements were performed on a BAS 100A electrochemical analyzer equipped with a video meter and an $\mathrm{XY}$ recorder. The electrochemical cell consists of three electrodes, $\mathrm{Ag} / \mathrm{AgCl}$ as reference, platinum wire as counter and platinum button as the working electrode. All the measurements were carried out in $\mathrm{CH}_{2} \mathrm{Cl}_{2}$ medium using $0 \cdot 1 \mathrm{M}$ tetrabutylammonium perchlorate as the supporting electrolyte. Porphyrin concentrations were maintained at $0.5 \mathrm{mM}$. All the solutions were purged with argon gas prior to electrochemical measurements and all the experiments were performed at room temperature.

\subsection{Methods}

The steady-state fluorescence spectra of the compounds were measured in $\mathrm{CH}_{2} \mathrm{Cl}_{2}$ at room temperature. The excitation wavelengths were kept at 515 and $417 \mathrm{~nm}$ of the unbrominated porphyrin $\left(\mathrm{H}_{2} \mathrm{TPP}\right)$ unit. $\mathrm{H}_{2} \mathrm{OBTPP}$ and $\mathrm{ZnOBTPP}$ absorb at the emission wavelength of the corresponding unbrominated porphyrin. The absorption correction was made by using the reported procedure. ${ }^{26}$ Unbrominated MTPPs $(M=2 \mathrm{H}, \mathrm{Zn}$ (II)) was employed as the reference standard. The singlet emission quantum yields $\left(\phi_{f}\right)$ of the bisporphyrins were calculated according to the literature method. ${ }^{27}$

$$
\left(\phi_{f}\right)_{s}=\left(\mathrm{OD}_{\mathrm{r}} \times A_{s} \times \phi_{f(r)}\right] /\left(\mathrm{OD}_{\mathrm{s}} \times A_{r}\right),
$$

where $\phi_{f}$ refers to fluorescence quantum yield and subscripts $r$ and $s$ indicate the reference and sample respectively. The area under the fluorescence band envelope is designated as $A$ and OD indicates the absorbance value at the excitation wavelength, kept at 0.05 to $0 \cdot 1$. All the $\phi_{f}$ values obtained from Soret excitation wavelengths are similar to those obtained from 515 or $550 \mathrm{~nm}$ excitation wavelengths.

\subsection{Synthesis of bisporphyrins}

The precursor compounds 5-(3' or 4'-hydroxyphenyl)$10,15,20$-tetraphenylporphyrin, $m$ or $p-\mathrm{H}_{2} \mathrm{TPP}(\mathrm{OH})^{28,29}$ and their 5 -( $3^{\prime}$ or $4^{\prime}$-(2-bromoethoxy/bisethyleneoxyphenyl))-10, 15, 20-triphenylporphyrin, $m$ or $p$ $\mathrm{H}_{2}$ TPP-1-Br and $m-\mathrm{H}_{2}$ TPP-2-Br were synthesised using the reported procedures. ${ }^{30}$

2.4a Synthesis of 2,3,7,8,12,13,17,18-octabromo-5(3' or 4'-(2-bromoethoxy phenyl)-10,15,20-triphenylporphyrin, $m$ or $p-\mathrm{H}_{2} \mathrm{OBTPP}-1-\mathrm{Br}$ : The perbrominated mono-functionalised free-base tetraphenylporphyrin was synthesised by the bromination reaction of the corresponding $\mathrm{Cu}$ (II) complex of the substituted porphyrin followed by acid demetallation reaction.

$\mathrm{Cu}$ (II) complex of the $m$ or $p-\mathrm{H}_{2} \mathrm{TPP}-1-\mathrm{Br}$ was synthesised using the literature procedure ${ }^{31}$, and the yield of the product being almost quantitative. Bromination of the $m$ or $p$-CuTPP-1-Br was carried out using reported procedure with slight modifications. ${ }^{23}$ The typical procedure for the synthesis of $m$ or $p$-CuOBTPP-1-Br is as follows: Liquid bromine $(0.6 \mathrm{ml}, 11.6 \mathrm{mmol})$ in $25 \mathrm{ml}$ of $\mathrm{CHCl}_{3}$ is added dropwise to a stirred solution of $m$ or $p$-CuTPP-1-Br $(0.25 \mathrm{~g}, 0.31 \mathrm{mmol})$ in $100 \mathrm{ml}$ of $\mathrm{CHCl}_{3}$ over a period of $30 \mathrm{~min}$ at room temperature. The reaction mixture is stirred for $4 \mathrm{~h}$. Then pyridine $(1.5 \mathrm{ml})$ in $40 \mathrm{ml}$ of $\mathrm{CHCl}_{3}$ is added dropwise for $30 \mathrm{~min}$. the solution is stirred for a further period of $12 \mathrm{~h}$. Further, the reaction mixture is treated with $20 \%$ aqueous sodium metabisulphite solution. The organic layer is dried over anhydrous $\mathrm{Na}_{2} \mathrm{SO}_{4}$ and the solvent removed under reduced pressure. The green product is chromatographed on a silica gel column using $\mathrm{CHCl}_{3}$ as the eluant. The yield of the product is about $0.36 \mathrm{~g}(70 \%)$.

The demetallation reaction is performed by the addition of conc. $\mathrm{H}_{2} \mathrm{SO}_{4}(0.5 \mathrm{ml})$ to a solution of $m$ or $p$-CuOBTPP-1-Br $(0.10 \mathrm{~g}, 0.07 \mathrm{mmol})$ in $50 \mathrm{ml}$ of $\mathrm{CHCl}_{3}$. The reaction mixture is then stirred for $30 \mathrm{~min}$. It is cooled in an ice bath and $100 \mathrm{ml}$ of distilled $\mathrm{H}_{2} \mathrm{O}$ is added slowly. The organic layer is 
separated and washed with saturated $\mathrm{NaHCO}_{3}$ $(50 \mathrm{ml})$ twice and dried over anhydrous $\mathrm{Na}_{2} \mathrm{SO}_{4}$. The organic layer is concentrated and chromatographed on to a silica gel column using $\mathrm{CHCl}_{3}$ as the eluant. The yield of the product is about $0.90 \mathrm{~g}$ (90\%). $m-\mathrm{H}_{2} \mathrm{OBTPP}-1-\mathrm{Br}: \delta_{\mathrm{H}}\left(270 \mathrm{MHz}, \mathrm{CDCl}_{3}\right.$, TMS): $8.20\left(m, 6 \mathrm{H}\right.$, triphenyl $\left.\mathrm{H}_{o}\right), 7 \cdot 77(m, 9 \mathrm{H}$, triphenyl $\left.\mathrm{H}_{m, p}\right), 7 \cdot 47$ ( $m, 4 \mathrm{H}$, substituted phenyl-H), $4.56\left(t, 2 \mathrm{H}, \mathrm{OCH}_{2}\right), 3 \cdot 81\left(t, 2 \mathrm{H}, \mathrm{CH}_{2} \mathrm{Br}\right),-1 \cdot 56(b s$, $2 \mathrm{H}, \mathrm{N}-\mathrm{H})$. UV-visible spectrum of $m-\mathrm{H}_{2} \mathrm{OBTPP}-1$ $\mathrm{Br}$ in $\mathrm{CH}_{2} \mathrm{Cl}_{2}$, nm (loge): 367 (4.87), 469 (5.30), 589 (4.16), 625 (4.12), 742 (3.97). $p-\mathrm{H}_{2} \mathrm{OBTPP}-1-\mathrm{Br}: \delta_{\mathrm{H}}$ (270 MHz, $\left.\mathrm{CDCl}_{3}, \mathrm{TMS}\right): 8.21$ ( $m, 6 \mathrm{H}$, triphenyl $\left.\mathrm{H}_{o}\right), 7.77\left(m, 9 \mathrm{H}\right.$, triphenyl $\left.\mathrm{H}_{m, p}\right), 7 \cdot 33(d, 2 \mathrm{H}$, substituted phenyl $\left.\mathrm{H}_{m}\right), 8 \cdot 12(d, 2 \mathrm{H}$, substituted phenyl $\left.\mathrm{H}_{o}\right), 4.58\left(t, 2 \mathrm{H}, \mathrm{OCH}_{2}\right), 3.84\left(t, 2 \mathrm{H}, \mathrm{CH}_{2} \mathrm{Br}\right),-1.57$ (bs, 2H, N-H). UV-visible in $\mathrm{CH}_{2} \mathrm{Cl}_{2}(\log \varepsilon): 364$ (4.80), 469 (5.20), 586 (4.26), 623 (4.22), 741 (3.96).

2.4b Synthesis of 2,3,7,8,12,13,17,18-octabromo5-(3' or 4'-(2-bromo bisethylene oxyphenyl)-10,15, 20-triphenylporphyrin, $\mathrm{m}-\mathrm{H}_{2} \mathrm{OBTPP}-2-\mathrm{Br}$ : This was prepared by the condensation of digol dibromide with $m-\mathrm{H}_{2} \mathrm{TPP}(\mathrm{OH})$ using the literature method. ${ }^{30}$ Further, the metallation of this derivative with $\mathrm{Cu}$ (II) followed by bromination of CuTPP-2-Br complex was carried out using the method described earlier (Yield: 65\%). Its free-base derivative, $\mathrm{H}_{2}$ OBTPP-2-Br is obtained by adopting acid demetallation procedure as described above. The yield of the product is $90 \% . \delta_{\mathrm{H}}\left(270 \mathrm{MHz}, \mathrm{CDCl}_{3}, \mathrm{TMS}\right)$ : $8.07\left(m, 6 \mathrm{H}\right.$, triphenyl $\left.\mathrm{H}_{o}\right), 7.75(m, 9 \mathrm{H}$, triphenyl $\left.\mathrm{H}_{m}\right), 7.57(m, 4 \mathrm{H}$, substituted phenyl- $\mathrm{H}), 4.42(t, 2 \mathrm{H}$, phenyl-O- $\left.\mathrm{CH}_{2}\right), 4.01\left(\mathrm{~m}, 4 \mathrm{H},-\mathrm{CH}_{2}-\mathrm{O}-\mathrm{CH}_{2}-\right), 3.61$ $\left(t, 2 \mathrm{H},-\mathrm{CH}_{2} \mathrm{Br}\right),-1.55(b s, 2 \mathrm{H}, \mathrm{N}-\mathrm{H})$. UV-visible in $\mathrm{CH}_{2} \mathrm{Cl}_{2}(\log \varepsilon)$ : 366 (4.75), 467 (5.25), 587 (4.30), $622(4 \cdot 25), 742(3.93)$.

2.4c Synthesis of ethoxy-bridged free base bisporphyrins: To a solution of dry DMF $(100 \mathrm{ml})$ containing $m$ or $p-\mathrm{H}_{2} \mathrm{TPP}(\mathrm{OH})(0.10 \mathrm{~g}, 16 \mathrm{mmol})$ and $m$ or $p$ - $\mathrm{H}_{2}$ OBTPP- $1-\mathrm{Br}(0.22 \mathrm{~g}, 0.16 \mathrm{mmol}), 0.5 \mathrm{~g}$ of anhydrous $\mathrm{K}_{2} \mathrm{CO}_{3}$ is added. The reaction mixture is stirred under anhydrous conditions at room temperature for $36 \mathrm{~h}$. At the end of this period, the reaction mixture is filtered to remove $\mathrm{K}_{2} \mathrm{CO}_{3}$. The solvent, $\mathrm{DMF}$, is evaporated under reduced pressure and chromatographed on an alumina column using $\mathrm{CHCl}_{3} /$ $\mathrm{C}_{6} \mathrm{H}_{12}(1: 3, v / v)$ solvent mixture as the eluant. The unreacted $m$ or $p-\mathrm{H}_{2} \mathrm{OBTPP}-1-\mathrm{Br}$ is collected as the first fraction followed by the desired free-base bisporphyrin, $m$ or $p-\mathrm{H}_{2}$ TPP-1- $\mathrm{H}_{2} \mathrm{OBTPP}$. The yield of the product is $0.16 \mathrm{~g}(50 \%)$. $p-\mathrm{H}_{2} \mathrm{TPP}-1-\mathrm{H}_{2} \mathrm{OBTPP}$ : $\delta_{\mathrm{H}}\left(270 \mathrm{MHz}, \mathrm{CDCl}_{3}, \mathrm{TMS}\right): 8.85(m, 8 \mathrm{H}, \beta-\mathrm{H})$, $8.21\left(m, 16 \mathrm{H}\right.$, phenyl $\left.\mathrm{H}_{o}\right), 7.77(m, 18 \mathrm{H}$, phenyl $\left.\mathrm{H}_{m, p}\right), 7.45\left(m, 4 \mathrm{H}\right.$, bridging phenyl- $\left.\mathrm{H}_{m}\right), 4.77(s$, $4 \mathrm{H}$, bridging $\left.\mathrm{C}_{2} \mathrm{H}_{4}\right),-2.75(s, 2 \mathrm{H}, \mathrm{N}-\mathrm{H}),-1.65$ (bs, 2H, N-H). Elemental analysis calcd. for $\mathrm{C}_{90} \mathrm{H}_{54} \mathrm{~N}_{8} \mathrm{O}_{2} \mathrm{Br}_{8}:$ C, 56.40; $\mathrm{H}, 2.73 ; \mathrm{N}, 5.85 \%$. Found: C, 56.10; H, 2.58; N, 5.93\%. FAB mass spectrum $(m / z): 1919 \cdot 10\left[(M+\mathrm{H})^{+}, 100 \%\right], 1839 \cdot 20$ $\left[(M+\mathrm{H})^{+}-\mathrm{Br}, \quad 11 \%\right] . \quad m-\mathrm{H}_{2}$ TPP-1- $\mathrm{H}_{2} \mathrm{OBTPP}: \quad \delta_{\mathrm{H}}$ $\left(270 \mathrm{MHz}, \mathrm{CDCl}_{3}, \mathrm{TMS}\right): 8.87(m, 8 \mathrm{H}, \beta-\mathrm{H}), 8.20$ $\left(m, 16 \mathrm{H}\right.$, phenyl $\left.\mathrm{H}_{o}\right), 7.75\left(m, 18 \mathrm{H}\right.$, phenyl $\left.\mathrm{H}_{m, p}\right)$, $7.45\left(m, 4 \mathrm{H}\right.$, bridging phenyl- $\left.\mathrm{H}_{m, p}\right), 4.75(s, 4 \mathrm{H}$, bridging $\left.\mathrm{C}_{2} \mathrm{H}_{4}\right),-2.80(s, 2 \mathrm{H}, \mathrm{N}-\mathrm{H}),-1.65(b s, 2 \mathrm{H}$, $\mathrm{N}-\mathrm{H})$. Elemental analysis calcd. for $\mathrm{C}_{90} \mathrm{H}_{54} \mathrm{~N}_{8} \mathrm{O}_{2} \mathrm{Br}_{8}$ : C, 56.34; H, 2.84; N, 5.84\%. Found: C, 56.10; H, $2 \cdot 58 ; \mathrm{N}, 5.93 \%$.

$2.4 \mathrm{~d}$ Synthesis of metallated bisporphyrins, $m$ or $p$ MTPP-1-MOBTPP (M=Zn (II), Cu (II)): Metal complexes of the bisporphyrins are prepared using the appropriate metal carrier. A typical procedure for the synthesis of the metallation reaction is as follows: Metal acetate $(0 \cdot 10 \mathrm{~g})$ in $15 \mathrm{ml}$ of methanol is added to a stirred solution of free-base porphyrin in $\mathrm{CHCl}_{3}(0.10 \mathrm{~g}, 0.052 \mathrm{mmol})$, and the reaction mixture was stirred at ambient temperature for $30 \mathrm{~min}$. The solvent is removed by distillation and the residue thus obtained is dissolved in $\mathrm{CHCl}_{3}$ and washed with distilled water. Bimetallic bisporphyrins are obtained by silica gel column chromatography using $\mathrm{CHCl}_{3}$ as the eluant. The yield of the product is almost quantitative. $m$-CuTPP-1-CuOBTPP: FAB mass spectrum $(m / z): 2041.8\left[(M+\mathrm{H})^{+}, 100 \%\right]$, $1963.9\left[(M+\mathrm{H})^{+}-\mathrm{Br}, 10 \%\right] . m$-ZnTPP-1-ZnOBTPP: $\delta_{\mathrm{H}}\left(270 \mathrm{MHz}, \mathrm{CDCl}_{3}, \mathrm{TMS}\right) 8.91(m, 8 \mathrm{H}, \beta-\mathrm{H}), 8.09$ $\left(m, 16 \mathrm{H}\right.$, phenyl $\left.\mathrm{H}_{o}\right), 7.69\left(m, 22 \mathrm{H}\right.$, phenyl $\left.\mathrm{H}_{m, p}\right)$, $4.58\left(s, 4 \mathrm{H}\right.$, bridging $\left.\mathrm{C}_{2} \mathrm{H}_{4}\right)$.

$2.4 \mathrm{e}$ Synthesis of bisethylene oxide bridged bisporphyrins, $\left(m-\mathrm{H}_{2} \mathrm{TPP}-2-\mathrm{H}_{2} \mathrm{OBTPP}\right)$ : Free-base bisporphyrin bearing bisethylene oxide spacer group is prepared by the condensation of $m-\mathrm{H}_{2} \mathrm{TPP}(\mathrm{OH})$ with the functionalised brominated $m-\mathrm{H}_{2} \mathrm{OBTPP}-2-\mathrm{Br}$ using the procedure employed for the synthesis of ethylene oxide-bridged bisporphyrins with slight modifications. The product is purified by alumina column using cyclohexane/chloroform $(1: 6, v / v)$ solvent mixture as the eluant. The yield of the prod- 
uct is about $45 \%$. Elemental analysis calcd for $\mathrm{C}_{92} \mathrm{H}_{58} \mathrm{~N}_{8} \mathrm{O}_{3} \mathrm{Br}_{8}:$ C, 56.30; $\mathrm{H}, 2.98 ; \mathrm{N}, 5.71 \%$. Found: $\mathrm{C}, 55.96, \mathrm{H}, 2.82, \mathrm{~N}, 5.55 \%$. FAB mass spectrum $\left.(\mathrm{m} / \mathrm{z}): 1963.6\left[(M+\mathrm{H})^{+}, 100 \%\right)\right], 1883 \cdot 5$ $\left[(M+\mathrm{H})^{+}-\mathrm{Br}, 9 \%\right] . \delta_{\mathrm{H}}\left(270 \mathrm{MHz}, \mathrm{CDCl}_{3}, \mathrm{TMS}\right):$ $8.85(m, 8 \mathrm{H}, \beta-\mathrm{H}), 8.18\left(m, 16 \mathrm{H}\right.$, phenyl $\left.\mathrm{H}_{o}\right), 7.67$ $\left(m, 18 \mathrm{H}\right.$, phenyl $\left.\mathrm{H}_{m, p}\right), 7 \cdot 40(m, 4 \mathrm{H}$, bridging phenyl $\left.\left.\mathrm{H}_{m, p}\right), 4.43\left[s, 4 \mathrm{H},\left(\mathrm{ph}-\mathrm{O}-\mathrm{CH}_{2}\right)_{2}\right)\right], 4.12(s, 4 \mathrm{H}$, $\left.\left(-\mathrm{CH}_{2}-\mathrm{O}-\mathrm{CH}_{2}-\right)\right),-2 \cdot 81(s, 2 \mathrm{H}, \mathrm{N}-\mathrm{H}),-1.65$ (bs, $2 \mathrm{H}, \mathrm{N}-\mathrm{H}) . m$-MTPP-2-MOBTPP (M $=\mathrm{Cu}$ (II) and $\mathrm{Zn}$ (II)) is prepared using the procedure employed for the synthesis of ethylene oxide-bridged porphyrins. The yield of the porphyrin is almost quantitative. $m$-ZnTPP-2-ZnOBTPP: ${ }^{1} \mathrm{H}$ NMR in $\mathrm{CDCl}_{3}$ : $8.88(\mathrm{~m}, 8 \mathrm{H}, \beta$-pyrrole-H), $8.08(\mathrm{~m}, 16 \mathrm{H}$, phenyl-o$\mathrm{H}), 7.63\left(m, 18 \mathrm{H}\right.$, phenyl $\left.\mathrm{H}_{m, p}\right), 7.40(m, 4 \mathrm{H}$, bridging phenyl $\left.\left.\mathrm{H}_{m, p}\right), 4 \cdot 11\left[s, 4 \mathrm{H},\left(\mathrm{ph}-\mathrm{O}-\mathrm{CH}_{2}\right)_{2}\right)\right], 3 \cdot 73$ $\left[s, 4 \mathrm{H},\left(-\mathrm{CH}_{2}-\mathrm{O}-\mathrm{CH}_{2}-\right)\right] . m$-CuTPP-2-CuOBTPP: FAB mass spectrum $(m / z): 2085.8 \quad\left((M+\mathrm{H})^{+}\right.$, $100 \%), 2006 \cdot 6\left[(M+\mathrm{H})^{+}-\mathrm{Br}, 9 \%\right]$.

\section{Results and discussion}

Bisporphyrins were synthesized as described in scheme 1. They are crystalline in nature and soluble in a variety of organic solvents. Integrity of the bisporphyrins was checked by UV-visible, ${ }^{1} \mathrm{H}$ NMR, $m$ - or $p-\mathrm{MTPP}(\mathrm{OH})$
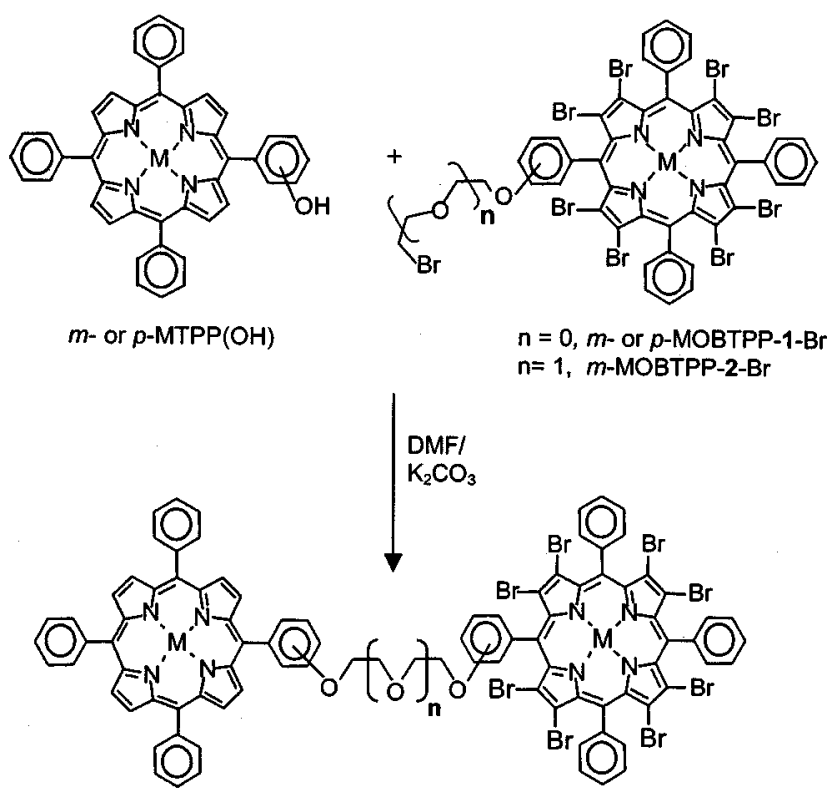

$\mathrm{M}=2 \mathrm{H}, \mathrm{Cu}(\mathrm{II}), \mathrm{Zn}(\mathrm{II})$ $\mathrm{n}=0$, MTPP $-1-$ MOBTPP $n=1$, MTPP. $2-$ MOBTPP

Scheme 1. Synthetic route for bisporphyrins. mass spectroscopies and also by elemental analysis. Optical absorption spectra of bisporphyrins were examined to probe the extent of intramolecular interactions in these bisporphyrins. Electronic absorption spectra of a representative bisporphyrins are shown in figure 1. A comparison is made with the absorption spectra of $1: 1$ synthetic mixtures of the individual components. Absorption spectral data of the bisporphyrins are shown in table 1. Bisporphyrins reveal characteristic Soret bands around $460-475 \mathrm{~nm}$ arising from the OBTPP moiety and in the range $410-425 \mathrm{~nm}$ region for unbrominated porphyrin TPP. It can be seen from the figure that ab-

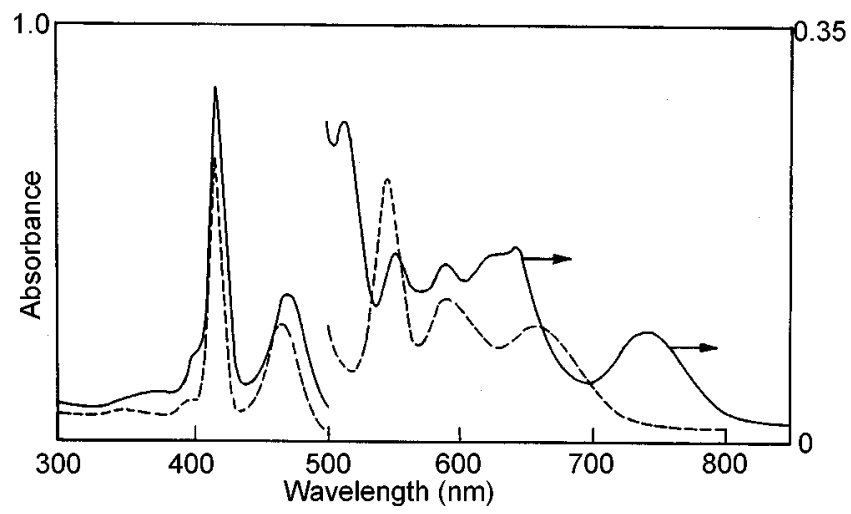

Figure 1. Electronic absorption spectra of $m-\mathrm{H}_{2} \mathrm{TPP}-2$ $\mathrm{H}_{2} \mathrm{OBTPP}(-)$ and $m$-ZnTPP-2-ZnOBTPP (----) in $\mathrm{CH}_{2} \mathrm{Cl}_{2}$ at $298 \mathrm{~K}$. Arrows indicate the absorbance for magnified $Q$ bands on the $y$-axis.

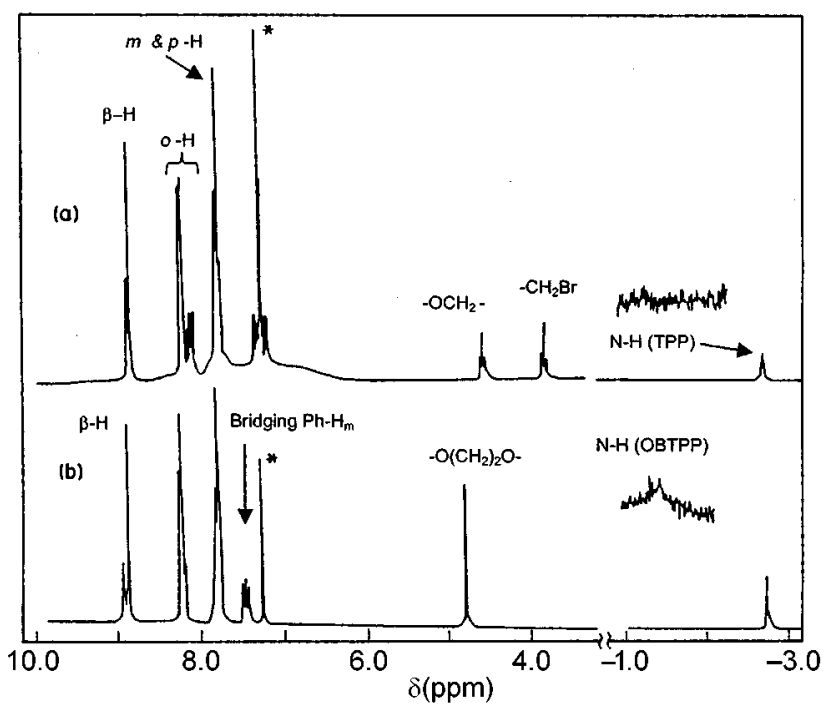

Figure 2. ${ }^{1} \mathrm{H}$ NMR spectrum of (a) $1: 1$ synthetic mixture of $p-\mathrm{H}_{2} \mathrm{TPP}(\mathrm{OH})$ and $p-\mathrm{H}_{2} \mathrm{OBTPP}-1-\mathrm{Br}$ and (b) bisporphyrin $p-\mathrm{H}_{2} \mathrm{TPP}-1-\mathrm{H}_{2} \mathrm{OBTPP}$ in $\mathrm{CDCl}_{3}$ at $298 \mathrm{~K}$. *Denotes the solvent peak. 
Table 1. Electronic absorption spectral data, of bisporphyrins in $\mathrm{CH}_{2} \mathrm{Cl}_{2}$ at $298 \mathrm{~K}$.

\begin{tabular}{|c|c|c|}
\hline Compound & $B$ bands (nm) & $Q$ bands (nm) \\
\hline$m-\mathrm{H}_{2} \mathrm{TPP}-1-\mathrm{H}_{2} \mathrm{OBTPP}$ & $\begin{array}{l}357(4 \cdot 65), 418(5 \cdot 68) \\
469(5 \cdot 3)\end{array}$ & $\begin{array}{l}514(4 \cdot 38), 550(4 \cdot 17) \\
589(4 \cdot 15), 629(s h) \\
644(4 \cdot 01), 739(3 \cdot 92)\end{array}$ \\
\hline m-СuТPР-1-СuОВТРP & $\begin{array}{l}361(4 \cdot 72), 415(5 \cdot 75) \\
449(s h), 465(5 \cdot 17)\end{array}$ & $\begin{array}{l}538(4 \cdot 44), 579(4 \cdot 34) \\
623(3 \cdot 86)\end{array}$ \\
\hline m-ZnTPP-1-ZnOBTPP & $\begin{array}{l}352(4 \cdot 78), 419(5 \cdot 80) \\
470(5 \cdot 17)\end{array}$ & $\begin{array}{l}548(4 \cdot 42), 594(4 \cdot 13) \\
664(4 \cdot 13)\end{array}$ \\
\hline$p-\mathrm{H}_{2} \mathrm{TPP}-1-\mathrm{H}_{2} \mathrm{OBTPP}$ & $\begin{array}{l}376(4 \cdot 76), 419(5 \cdot 68) \\
472(5 \cdot 31)\end{array}$ & $\begin{array}{l}514(4 \cdot 39), 551(4 \cdot 19) \\
590(4 \cdot 13), 628(s h) \\
644(4 \cdot 24), 748(3 \cdot 94)\end{array}$ \\
\hline p-СuTPP-1-CuOBТРP & $\begin{array}{l}364(4 \cdot 65), 416(5 \cdot 73) \\
450(s h), 469(5 \cdot 22)\end{array}$ & $\begin{array}{l}539(4 \cdot 46), 581(4 \cdot 30) \\
625(3 \cdot 94)\end{array}$ \\
\hline p-ZnTPP-1-ZnOBTPP & $\begin{array}{l}351(4 \cdot 69), 420(5 \cdot 80) \\
471(5 \cdot 48)\end{array}$ & $\begin{array}{l}549(4 \cdot 45), 592(4 \cdot 16) \\
667(4 \cdot 18)\end{array}$ \\
\hline$m-\mathrm{H}_{2} \mathrm{TPP}-2-\mathrm{H}_{2} \mathrm{OBTPP}$ & $\begin{array}{l}372(4 \cdot 85), 418(5 \cdot 72) \\
469(5 \cdot 33)\end{array}$ & $\begin{array}{l}513(4 \cdot 42), 551(4 \cdot 18) \\
631(s h), 642(4 \cdot 20)\end{array}$ \\
\hline m-CuTPP-2-CuOBTPP & $\begin{array}{l}363(4 \cdot 75), 415(5 \cdot 73) \\
446(s h), 466(5 \cdot 17)\end{array}$ & $\begin{array}{l}538(4 \cdot 42), 579(4 \cdot 30) \\
624(s h)\end{array}$ \\
\hline m-ZnTPP-2-ZnOBTPP & $\begin{array}{l}351(4 \cdot 78), 419(5 \cdot 74) \\
468(5 \cdot 36)\end{array}$ & $\begin{array}{l}548(4 \cdot 34), 591(4 \cdot 07) \\
658(3 \cdot 98)\end{array}$ \\
\hline $1: 1, \mathrm{H}_{2} \mathrm{OBTPP} / \mathrm{H}_{2} \mathrm{TPP}$ & $\begin{array}{l}367(4 \cdot 87), 417(5 \cdot 68) \\
469(5 \cdot 30)\end{array}$ & $\begin{array}{l}514(4 \cdot 38), 550(4 \cdot 19) \\
589(4 \cdot 16), 629(s h) \\
644(4 \cdot 23), 742(3 \cdot 97)\end{array}$ \\
\hline $1: 1, \mathrm{CuOBTPP/CuTPP}$ & $\begin{array}{l}360(4 \cdot 71), 415(5 \cdot 75) \\
448(s h), 464(5 \cdot 16)\end{array}$ & $\begin{array}{l}538(4 \cdot 47), 579(4 \cdot 31) \\
623(3 \cdot 92)\end{array}$ \\
\hline $1: 1, \mathrm{ZnOBTPP} / \mathrm{ZnTPP}$ & $\begin{array}{l}353(4 \cdot 74), 419(5 \cdot 81) \\
466(5 \cdot 40)\end{array}$ & $\begin{array}{l}548(4 \cdot 43), 590(4 \cdot 17) \\
655(4 \cdot 05)\end{array}$ \\
\hline
\end{tabular}

${ }^{a}$ Values in parentheses refer to $\log \varepsilon ;{ }^{b}$ error in $\lambda_{\max }= \pm 1.0 \mathrm{~nm}$

sorption bands in the visible region $(500-800 \mathrm{~nm})$ overlap considerably. The position of the absorption spectral bands of the bisporphyrins bears close resemblance to the spectra obtained for $1: 1$ synthetic mixtures with comparable molar absorption coefficients. A variation in position of the attachment (para or meta) or the length of the linkage group (ethylene oxide and bisethylene oxide) in these bisporphyrins do not show any significant differences in their absorption spectral features.

${ }^{1} \mathrm{H}$ NMR spectra of the bisporphyrins are very useful in characterization of the compounds. Figure 2 shows the ${ }^{1} \mathrm{H}$ NMR spectrum of bisporphyrin $p$ $\mathrm{H}_{2}$ TPP-1- $\mathrm{H}_{2} \mathrm{OBTPP}$ along with that of the synthetic mixture of the monomeric entities. The bisporphyrins exhibit proton resonances characteristic of $\beta$-pyrrole, unsubstituted meso-phenyl groups, sub- stituted meso-phenyl and bridging alkyl ether protons. The integrated intensities of the proton resonances have been useful in identifying the number of protons in the respective bisporphyrins. In the case of bisporphyrins, the imino protons resonate around $-1.65 \mathrm{ppm}$, characteristic of brominated porphyrin, while the resonance at $-2.80 \mathrm{ppm}$ arises from the unbrominated porphyrin unit. The presence of covalent linkages in the bisporphyrin systems is shown by comparison of the ${ }^{1} \mathrm{H}$ NMR spectra of the bisporphyrins with that of the $1: 1$ synthetic mixture of the constituents. It can be seen that the ether protons in the intermolecular mixtures resonate as two triplets centred at $3.73 \mathrm{ppm}\left(\mathrm{CH}_{2} \mathrm{Br}\right)$ and $4.48 \mathrm{ppm}$ $\left(\mathrm{OCH}_{2}\right)(\mathrm{J} \sim 4 \mathrm{~Hz})$ in the $p-\mathrm{H}_{2} \mathrm{OBTPP}-1-\mathrm{Br}$ compound while it appears as a singlet at $4.77 \mathrm{ppm}$ in the bisporphyrin ( $\left.p-\mathrm{H}_{2} \mathrm{TPP}-1-\mathrm{H}_{2} \mathrm{OBTPP}\right)$ owing to 
the symmetric disposition of the ethylene oxide protons between the porphyrin units. The dimetallic bisporphyrin, $p$ or $m$-ZnTPP-1-ZnOBTPP shows resonances not significantly different from those of the free-base bisporphyrin except for the absence of the imino proton resonances. The bisethylene oxidebridged bisporphyrin, $m-\mathrm{H}_{2}$ TPP-2- $\mathrm{H}_{2} \mathrm{OBTPP}$ shows resonances quite similar to that the $m-\mathrm{H}_{2} \mathrm{TPP}-1$ $\mathrm{H}_{2} \mathrm{OBTPP}$ complex with two singlets for the bridging bisethylene oxide group at $4.43 \mathrm{ppm}\left(-\mathrm{O}-\mathrm{CH}_{2}\right)$ and $4.12 \mathrm{ppm}\left(\mathrm{CH}_{2}-\mathrm{O}-\mathrm{CH}_{2}\right)$ groups, whereas the synthetic mixture shows two triplets at $4.42 \mathrm{ppm}$ $\left(\mathrm{OCH}_{2}\right)$ and $3.77 \mathrm{ppm}\left(\mathrm{CH}_{2} \mathrm{Br}\right)$, and a multiplet centred at $4.01 \mathrm{ppm}\left(-\mathrm{CH}_{2}-\mathrm{O}-\mathrm{CH}_{2}-\right)$. The ${ }^{1} \mathrm{H}$ NMR spectrum of the bisporphyrins does not show direct evidence for the existence of any strong intramolecular interactions in bisporphyrins.

Cyclic voltammetric studies were performed to determine the electrochemical redox potentials of bisporphyrins to examine the possible presence of intermolecular interactions. A representative voltammogram of $m$-CuTPP-1-CuOBTPP is shown in figure 3 and the data of all the bisporphyrins are summarised in table 2 . The majority of the bisporphyrins exhibit reversible potentials involve a oneelectron process. In some cases, the potentials overlap with one another and the differential pulse voltammetry is indicative of more than one electron transfer process. Under similar conditions, the redox
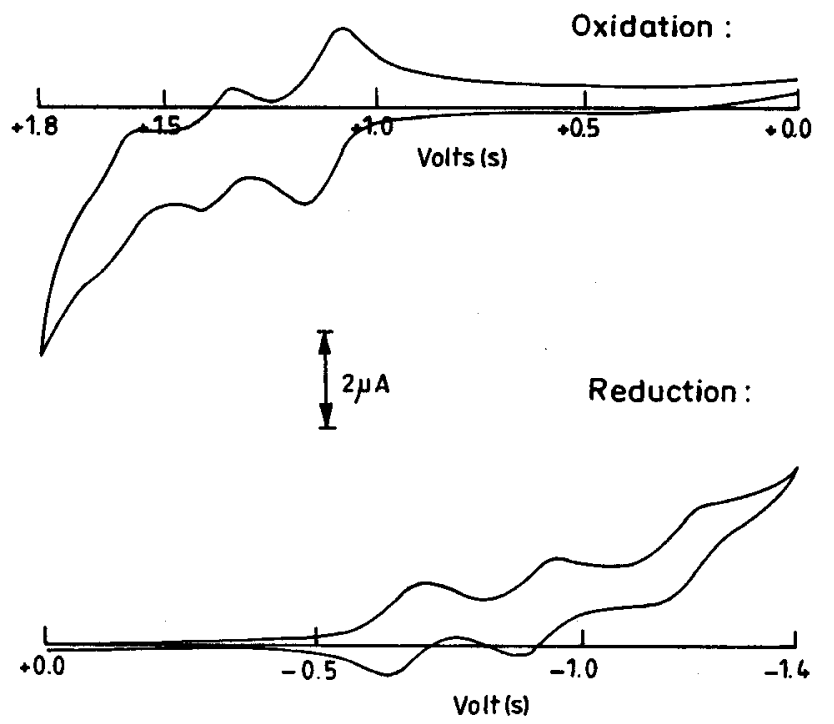

Figure 3. Cyclic voltammograms of $m$-CuTPP-1CuOBTPP in $\mathrm{CH}_{2} \mathrm{Cl}_{2}$ with $0 \cdot 1 \mathrm{M}$ TBAHFP at $298 \mathrm{~K}$ with a scan rate of $100 \mathrm{mV} / \mathrm{s}$. potentials of the $1: 1$ synthetic mixtures of TPP and OBTPP were also determined and are listed in table 2. The observed redox data of the individual porphyrins $\left(\mathrm{TPPs}^{32}\right.$ and OBTPPs ${ }^{23}$ ) are fairly similar to that of the literature values. It is reported earlier that the MOBTPPs show a marginal anodic shift of the oxidation potentials with a substantial anodic shift in the reduction potentials of the ring-centred redox potentials relative to that of the corresponding MTPPs. The intramolecular interactions in these bisporphyrins would shift redox potentials cathodically for OBTPP centre while it is anodic shift in redox potentials for MTPPs. It can be seen from the data that generally in bisporphyrins, the first redox potentials of OBTPP are shifted cathodically by 40 $80 \mathrm{mV}$, while that of TPP moieties show an anodic shift (30-60 mV). In some cases, especially for the di-zinc bisporphyrins, the oxidation potentials overlap considerably due to the close proximity of the potentials. The cathodic shift of redox potentials of OBTPP and the anodic shift of TPP potentials indicate minimal intramolecular interactions in these bisporphyrins.

In order to probe the possible existence of intramolecular electron or energy transfer (singletsinglet) reactions in these bisporphyrins, steady state fluorescence spectra were obtained in $\mathrm{CH}_{2} \mathrm{Cl}_{2}$. A typical fluorescence spectrum of bisporphyrin is shown in figure 4 . The fluorescence spectra of bisporphyrins are compared with the spectra of the corresponding $1: 1$ synthetic mixture of their constituents. For all the compounds, the excitation wavelength was kept at $419 \mathrm{~nm}$. For comparison, fluorescence quantum yields of the TPP derivatives $\left(\mathrm{H}_{2} \mathrm{TPP}\right.$ and $\mathrm{ZnTPP}$ ) were also determined and are listed in table 3. Observed data for MTPPs $(\mathrm{M}=2 \mathrm{H}, \mathrm{Zn}$ (II)) are similar to reported values. ${ }^{33}$ The singlet emission bands of $\mathrm{H}_{2} \mathrm{TPP}(651,714 \mathrm{~nm})$ overlap considerably with the absorption spectra of $\mathrm{H}_{2} \mathrm{OBTPP}$ (626, $743 \mathrm{~nm}$ ). Similarly, the emission bands of ZnTPP $(596,646 \mathrm{~nm})$ overlap with the absorption spectra of ZnOBTPP (594, $656 \mathrm{~nm}$ ). It can be seen that the positions of the emission bands of bisporphyrins are not altered significantly. However, the values of the quantum yields decrease dramatically relative to those of their $1: 1$ synthetic mixtures. Quantum yields of the synthetic mixtures $\left(\mathrm{H}_{2} \mathrm{TPP} / \mathrm{H}_{2} \mathrm{OBTPP}\right.$ and ZnTPP/ZnOBTPP) show a marginal decrease relative to the corresponding $\mathrm{H}_{2} \mathrm{TPP}$ and ZnTPP units. The unbrominated porphyrin (TPP) unit is expected to act as a donor, while the brominated 
Table 2. Half-wave potentials ${ }^{\mathrm{a}}$ (vs $\mathrm{Ag} / \mathrm{AgCl}, \mathrm{V}$ ) of bisporphyrins in $\mathrm{CH}_{2} \mathrm{Cl}_{2}$ using $0 \cdot 1 \mathrm{M} \mathrm{TBAPF}_{6}$ as the supporting electrolyte at $298 \mathrm{~K}$.

\begin{tabular}{|c|c|c|c|c|c|c|c|c|}
\hline \multirow[b]{2}{*}{ Bisporphyrin } & \multicolumn{4}{|c|}{ Oxidation } & \multicolumn{4}{|c|}{ Reduction } \\
\hline & I & II & III & IV & I & II & III & IV \\
\hline$m-\mathrm{H}_{2} \mathrm{TPP}-1-\mathrm{H}_{2} \mathrm{OBTPP}$ & $1 \cdot 05^{\mathrm{b}}$ & $1 \cdot 18$ & $1 \cdot 40^{\mathrm{b}}$ & - & -0.62 & $-1 \cdot 04$ & $-1 \cdot 40$ & - \\
\hline$m$-ZnTPP-1-ZnOBTPP & $0 \cdot 93$ & $1 \cdot 19$ & - & - & $-0 \cdot 86$ & $-1 \cdot 36^{\mathrm{b}}$ & - & - \\
\hline$m$-CuTPP-1-CuOBTPP & $1 \cdot 17^{\mathrm{b}}$ & 1.42 & 1.63 & - & -0.63 & $-0 \cdot 88$ & $-1 \cdot 14$ & $-1 \cdot 53^{\mathrm{c}}$ \\
\hline$m-\mathrm{H}_{2}$ TPP-2- $\mathrm{H}_{2} \mathrm{OBTPP}$ & $1 \cdot 08^{b}$ & $1 \cdot 19$ & $1 \cdot 40$ & - & $-0 \cdot 57$ & $-1 \cdot 01$ & $-1 \cdot 33$ & - \\
\hline$m$-ZnTPP-2-ZnOBTPP & $0 \cdot 94$ & $1 \cdot 21$ & - & - & $-0 \cdot 92$ & $-1 \cdot 23$ & $-1 \cdot 41$ & - \\
\hline$m$-CuTPP-2-CuOBTPP & $1 \cdot 17$ & $1 \cdot 37$ & $1 \cdot 58$ & - & -0.67 & $-0 \cdot 91$ & $-1 \cdot 18$ & $-1 \cdot 52^{\mathrm{c}}$ \\
\hline$p$-ZnTPP-1-ZnOBTPP & 0.98 & $1 \cdot 25$ & - & - & $-0 \cdot 91$ & $-1 \cdot 30$ & $-1 \cdot 65$ & - \\
\hline$p$-СuТPР-1-СuОВТРP & $1 \cdot 10$ & 1.40 & $1 \cdot 62$ & - & -0.63 & $-0 \cdot 90$ & $-1 \cdot 03$ & $-1 \cdot 40$ \\
\hline $1: 1, \mathrm{H}_{2} \mathrm{TPP} / \mathrm{H}_{2} \mathrm{OBTPP}$ & $1 \cdot 00$ & $1 \cdot 14$ & $1 \cdot 35$ & - & $-0 \cdot 57$ & $-0 \cdot 92$ & $-1 \cdot 10$ & $-1 \cdot 35$ \\
\hline $1: 1, \mathrm{ZnTPP} / \mathrm{ZnOBTPP}$ & $0 \cdot 81$ & $0 \cdot 96$ & $1 \cdot 19$ & - & -0.93 & $-1 \cdot 33$ & - & - \\
\hline $1: 1, \mathrm{CuTPP} / \mathrm{CuOBTPP}$ & $1 \cdot 01$ & $1 \cdot 35$ & $1 \cdot 55$ & - & $-0 \cdot 59$ & $-0 \cdot 85$ & $-1 \cdot 09$ & $-1 \cdot 59^{c}$ \\
\hline
\end{tabular}

${ }^{\mathrm{a}}$ Error $\pm 15 \mathrm{mV} ;{ }^{\mathrm{b}}$ quasireversible; ${ }^{\mathrm{c}}$ data from differential pulse voltammetry

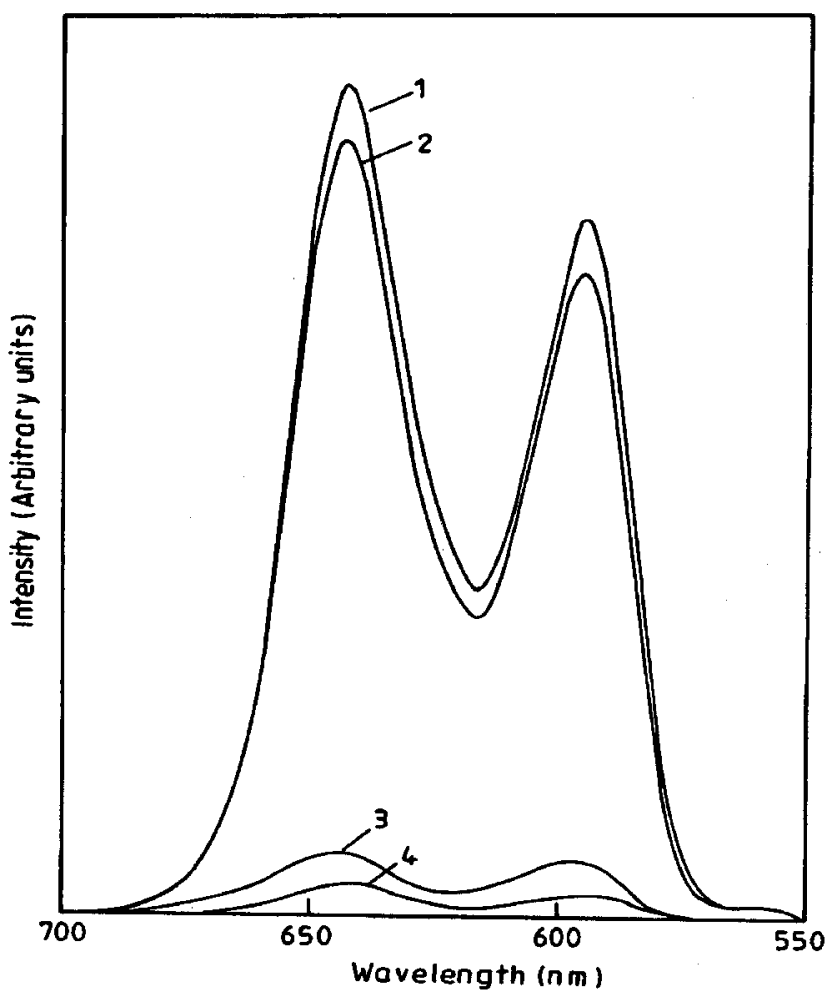

Figure 4. Fluorescence spectra of (1) ZnTPP, (2) $1: 1$ synthetic mixture of ZnTPP and ZnOBTPP, (3) $m$-ZnTPP2-ZnOBTPP and (4) $m$-ZnTPP-1-ZnOBTPP in $\mathrm{CH}_{2} \mathrm{Cl}_{2}$ at $298 \mathrm{~K}$. The excitation wavelength is at $419 \mathrm{~nm}$.

porphyrin acts as an acceptor. Steady-state fluorescence quantum yields obtained in this study permit us to calculate ${ }^{34}$ the efficiency of quenching, $\eta_{\mathrm{ss}}=$ $\left(1-\phi_{\mathrm{DA}} / \phi_{\mathrm{D}}\right) \times 100$ where $\phi_{\mathrm{DA}}$ and $\phi_{\mathrm{D}}$ are the quantum yields of the bisporphyrin ( $m$ or $p-\mathrm{H}_{2} \mathrm{TPP}-1-$
Table 3. Steady-state singlet emission data of bisporphyrins in $\mathrm{CH}_{2} \mathrm{Cl}_{2}$ at $298 \mathrm{~K}$.

\begin{tabular}{|c|c|c|c|}
\hline Compound & $\lambda_{e m}(\mathrm{~nm})$ & $\phi_{f}^{\mathrm{a}}$ & $\eta_{\mathrm{ss}}$ \\
\hline$m-\mathrm{H}_{2} \mathrm{TPP}-1-\mathrm{H}_{2} \mathrm{OBTPP}$ & 652,713 & $0 \cdot 0019$ & $98 \cdot 52$ \\
\hline$m$-ZnTPP-1-ZnOBTPP & 596,645 & $0 \cdot 0007$ & $99 \cdot 80$ \\
\hline$p-\mathrm{H}_{2} \mathrm{TPP}-1-\mathrm{H}_{2} \mathrm{OBTPP}$ & 650,715 & $0 \cdot 0032$ & $97 \cdot 60$ \\
\hline$p$-ZnTPP-1-ZnOBTPP & 598,644 & 0.0027 & $91 \cdot 88$ \\
\hline$m$ - $\mathrm{H}_{2} \mathrm{TPP}-2-\mathrm{H}_{2} \mathrm{OBTPP}$ & 651,716 & 0.0015 & $98 \cdot 82$ \\
\hline$m$-ZnTPP-2-ZnOBTPP & 597,646 & $0 \cdot 0011$ & $96 \cdot 72$ \\
\hline $\mathrm{H}_{2} \mathrm{TPP} / \mathrm{H}_{2} \mathrm{OBTPP}$ & 652,715 & $0 \cdot 124$ & \\
\hline ZnTPP/ZnOBTPP & 597,645 & 0.029 & \\
\hline $\mathrm{H}_{2} \mathrm{TPP}$ & 651,714 & $0 \cdot 130$ & \\
\hline ZnTPP & 596,646 & $0 \cdot 033$ & \\
\hline
\end{tabular}

${ }^{\mathrm{a}}$ Uncertainty in values, $\pm 8 \%$

$\mathrm{H}_{2} \mathrm{OBTPP}$ ) and $\mathrm{H}_{2}$ TPP respectively. An examination of the data in table 3 shows that the singlet emission of the TPP entity is quenched very efficiently in all the bisporphyrins and less so, if the two units are mixed intermolecularly. Interestingly, the emission spectrum of the TPP overlaps with the absorption spectrum of the OBTPP indicative of the possible existence of energy transfer from the TPP unit to the non-radiative OBTPP unit.

The electron transfer process from the donor (TPP) to acceptor (OBTPP) can be calculated from the expression, $\Delta G_{\mathrm{et}}=E_{c t}-E_{s}$ where $\Delta G_{e t}$ represents the free-energy change accompanied by the excited state electron transfer process in bisporphyrins. $E_{c t}$ is the energy of the charge transfer state calculated from the difference between the first oxidation and first reduction potentials of TPP and OBTPP units respectively. $E_{s}$ refers to the energy of the singlet- 
excited state of the TPP entity. The electrochemical redox data shown in table 2 indicate that the $\Delta G_{e t}$ is exergonic. The fluorescence spectrum of the bisporphyrins may afford a large local concentration of the brominated porphyrin in the neighbourhood of the unbrominated porphyrin $\left(\mathrm{H}_{2} \mathrm{TPP}\right.$ or ZnTPP) resulting in the possible efficient quenching of fluorescence of the unbrominated TPP entity.

\section{Summary}

Synthesis and characterization of a new class of bisporphyrins, bearing electron-deficient (OBTPP) and electron-rich (TPP) units have been presented. The electrochemical redox properties of free-base and bimetallic complexes of bisporphyrins show weak intramolecular interactions. Steady-state singlet emission studies on the bisporphyrins show a dramatic decrease in quantum yields with high efficiency of singlet-state quenching of the TPP unit in the bisporphyrins. Electrochemical redox and fluorescence studies show possible intramolecular interactions in these bisporphyrins.

\section{Acknowledgement}

This work was supported by the Department of Science and Technology, Government of India.

\section{References}

1. Gust D, Moore T A, Moore, A L, Leggett L, Lin S, De Graziano J M, Hermant R M, Nicodem D, Craig P, Seely G R and Neiman R A 1993 J. Phys. Chem. 977926

2. (a) Wasielski M R 1992 Chem. Rev. 92 435; (b) Gust D and Moore T A 1989 Tetrahedron 454683

3. Osuka A, Maruyama K, Mataga M, Asahi T, Yamazaki I and Tamai N 1990 J. Am. Chem. Soc. 112 4958

4. Bookster B G and Bruice T C 1991 J. Am. Chem. Soc. 1134208

5. Eaton S S, Eaton G R and Chang C K $1980 \mathrm{~J}$. Am. Chem. Soc. 1073177

6. Senge M O, Kalisch W W and Ruhlandt-Senge K 1996 J. Chem. Soc. Chem. Commun. 2149

7. Twyman L J and Sanders J K M 1999 Tetrahedron Lett. 406681
8. Collman J P, Wagenknecht P S and Huchison J E 1994 Angew. Chem., Int. Ed. Eng. 33 1537, and references cited therein

9. Toshiro K, Aida T, Zheng L Y, Kinbara K, Saigo K, Sakamoto S and Yamaguchi K 1999 J. Am. Chem. Soc. 1219477

10. Wylie R S, Levy E G and Sanders J K M 1997 Chem. Commun. 1611

11. Wagner R W, Johnson T E, Li F and Lindsey J S 1995 J. Org. Chem. 605266

12. Boxer S G 1983 Biochim. Biophys. Acta 72965

13. Dolphin D, Hiom J and Paine III J B 1981 Heterocycles 16417

14. Harriman A 1988 In Supramolecular photochemistry (ed.) V Balzani (New York: Kluwer Academic) p. 297

15. DiMagno S G and Therien M J 1994 Science 264 1105

16. Paolesse R, Tagliatesta P and Boschi T 1996 Tetrahedron Lett. 372637

17. Iida K, Nango N M, Okada K, Hikita M and Matsura M 1995 Bull. Chem. Soc. Jpn. 681959

18. Sen A and Krishnan V 1998 Chem. Phys. Lett. 294 499

19. Tsuchiya S 1999 J. Am. Chem. Soc. 12148

20. Ravikanth M and Chandrashekar T K 1995 Struct. Bonding (Berlin) 65105

21. Dolphin D, Traylor T G and Xie L Y 1997 Acc. Chem. Res. 30 251, and references therein

22. Adler A D, Longo F R, Goldmacher J, Assour J and Korchakoff L 1967 J. Org. Chem. 32476

23. Bhyrappa P and Krishnan V 1991 Inorg. Chem. 30 239

24. Pederson C J 1967 J. Am. Chem. Soc. 897017

25. Perrin D D and Armarego W L F 1988 Purification of laboratory chemicals 3rd edn (New York: Pergamon Press)

26. Demas J N and Adamson A W $1973 \mathrm{~J}$. Am. Chem. Soc. 897017

27. Austin E and Gouterman M 1978 Bioinorg. Chem. 9 281

28. Rao P D, Dhanalekshmi S, Littler B J and Lindsey J S 2000 J. Org. Chem. 657323

29. Little R, Anton J A, Loach P A and Ibers J A 1975 J. Am. Chem. Soc. 97343

30. Jeyakumar D and Krishnan V 1983 New. J. Chem. 7 697

31. Adler A D, Longo R R, Kampas F and Kim J $1970 \mathrm{~J}$. Inorg. Nucl. Chem. 322443

32. Kadish KM and Morrison M M 1977 Bioinorg. Chem. 7107

33. Gouterman M 1978 In The porphyrins (ed.) D Dolphin (New York: Academic Press) vol. 3, part A. p. 1

34. Lakowiz J R 1999 Principles of fluorescence spectroscopy (New York: Kluwer Academic/Plenum Publishers) 